\title{
A Community of Shared Future in David Barnett's Calling Major Tom
}

\author{
Yuan Shen ${ }^{1, *}$ Quan Yuan ${ }^{1}$
}

\author{
${ }^{1}$ University of Jinan, Ji'nan, Shandong 250022, China \\ *Corresponding author. Email: sfl_sheny@ujn.edu.cn
}

\begin{abstract}
This essay analyzes the content of Calling Major Tom in the perspective of community. Firstly, from the perspective of the relationship community, it shows the parental love, brotherhood and intergenerational communication. Secondly, due to the tense pace of life and continuous difficulties in today's society, through the family in crisis, the communication across the space and the protagonists' longing for home, the paper expounds the community of place. Finally, through the mutual connection and common psychological characteristics of characters, it shows the author's writing intention and draws closer to the community of mind. The context analysis of Calling Major Tom in the perspective of community helps unveil the writer's diverse visions and his understanding of a community of shared future for mankind, and his thoughts on the connection of British society.
\end{abstract}

Keywords: Calling Major Tom, David Barnett, Community.

\section{INTRODUCTION}

The discussion of the community in the west began with the publication of Plato's Utopia. It is the trending topic that scholars in European sociology, philosophy and other fields have always discussed. Hegel, Marx and Tönnies' views occupy the main position in the exploration of the community. Among them, Tönnies (1980: 33) [14] is the epitome of the community thought, and his theory comes from the German traditional view of the basic existence of human beings: through the abstraction of the community formed by the smallscale living of the Germanic people, the community is considered as "The relationship itself, and also the resulting association, is conceived of either as real and organic life - this is the essential characteristic of the Gemeinschaft (community)" (Tönnies, 1980: 33) [14]. Tönnies divides the community into Community of Blood, Community of Place and Community of Mind. Among these, the most important part is the Community of Mind. "Gemeinschaft of mind expresses the community of mental life. In conjunction with the others, this last

*Funds: This is a representative paper of "Shandong Higher Education Research Projects in Humanities and social Sciences"(Project No. J18RA247) and "Shandong Social Science Planning Fund Projects"(Project No. 19DWWJ02). type of Gemeinschaft represents the truly human and supreme form of community" (Tönnies, 1980: 42) [14]. While in China, people lay more stress on the sense of belonging to their hometown. On this point, Fei Xiaotong (2012: 4) [4], in his masterpiece From the soil — The Foundations of Chinese Society, uses Tönnies' theory to define the local society as a xiangtu community: "In sociology, we often divide two different kinds of societies: one is a society that has no specific purpose but grows up together; the other is a society formed to accomplish a task; in the words of Tönnies, the former mode of society is Gemeinschaft, and the latter mode of society is Gesellschaft. The first type of society can be deemed as one based on rites and customs (li and $\mathrm{su}$ ), and the second as one based on law and reason (fa and li). The relationship between the first type of society as one based on ritual and customs (li and su) and Gemeinschaft is expressed clear" (Huang, 2016: 47) [5]. This thesis aims to analyze the three different aspects of Tönnies' community and combines these community ideas with a contemporary novel to interpret the proposition of the community of shared future from a new perspective. 
David Barnett, a new award-winning British writer, was born in Wigan, Lancashire, England on 11 January, 1970. He has published several books, including Hinterland (2005), Angelglass (2007) and The Janus House and Other Two-Faced Tales (2009). His works contain novels and short stories depicting British common life with the most common language, calm tone and great humor, which sometimes seems to make the story read less depressing. Calling Major Tom tells a story of escaping from fear but eventually returning for love. Two families who have never met each other before have established their ties in an incredible way. Families in despair and a young man with his back to the wall have become the hope and spiritual sustenance of each other.

Astronauts are a work of hope and courage, representing the dream of human beings to explore new universal space and future career. One out of ten million excellent people can hardly be competent at this job and no one has ever imagined that a person who is ordinary, flawed or even a little bit defeated by life's setbacks to shoulder this kind of heavy responsibility.

Nevertheless, in Calling Major Tom, there is such an astronaut "Thomas", also known as "Major Tom": his late childhood is shadowed, his love is broken, and his work is all about monotonous tasks. Even the marriage he wove is shattered by his own hands. If there is no accident, he will spend the rest of his lifetime in frustration.

However, an accident suddenly happened. The original astronaut died of a vital heart attack. Thomas decided to take the place on his own, for he thought that it was an ideal way of "suicide" for the hopeless life. In space, Thomas originally intended to contact his ex-wife by phone her old number and but somehow answered by an old lady who is not very conscious. He has been connected with a family with a lot of crises since then. In the process of helping them, he has also helped himself be out of the childhood shadow and regaining his lifelong hope.

David Barnett's mold-breaking structure, which switches between different characters and time with each chapter, has become a favorite trick of modern novelists - but the book also captures something timeless: how community can cure innermost sadness on people-to-people connection. Although there is little research on David Barnett's works, David Barnett is widely praised among contemporary writers. Katie Marsh, author of $M y$ Everything, claimed that "it is a book about loneliness, about bravery, about the walls we all put up to protect ourselves and about how it is never ever too late to try to change." Lucy Diamond, author of Searching for a Silver Lining commented that "A gorgeously quirky story about families, forgiveness and unexpected friendships — sheer joy" (Barnett, 2017: 6) [1] .

There is an intimacy to seeing people of every type thrown together without any social trappings. The key to the changing fate of the two vulnerable families is the call from space. It was a desperate phone call. Thomas's ex-wife changed her number and was not willing to give him the last chance to say goodbye or explain about his deeds. But at that time a broken family appeared in the same abandoned journey of Thomas, which is the natural connection. The will and spirit of kinship is not confined within the walls of the house nor bound up with physical proximity (Tönnies, 1980: 43) [14]. That is to say, the connection between people emphasized in the community is not compulsory, but naturally established in the communication between people.

\section{COMMUNITY OF BLOOD}

Barnett's novel explored British common life and a quirky miracle of happenstance, exiled the struggles of every man in the developed world. His writing is widely praised for its compassion toward the destitute and the displaced. His writing features are explained in this paper through the community of blood.

\subsection{Parental Love}

The novel mainly involves two families: the first is the Thomas family. The different interests between Thomas and his father pave the way for the breaking moment of their relationship, which caused by the later discovery of his father's infidelity due to the movie watching event. "Instead he says, 'I was never what dad wanted in a son.' Theresa looks shocked. 'That's a terrible thing to say. He doted on you.' 'He did until Peter came along. Peter's more like him. He's into football and climbing trees and cars and all that boy stuff. Dad never understood me. Never got anything I was into. Never understood the science, never liked music, never read books. He thought I was weird. He thought I was soft. I think he probably thought I was gay" (Barnett, 2017: 71) [1]. His brother's accidental dead for falling into the water, and he lives with a pervasive sense of guilt. And then his 
mother, who was extremely vulnerable due to his father's death, hid a letter from his girlfriend, which led to the couple breaking up, and the reunion of the two people years later has turned them to a stranger. Finally, the failure of his marriage made him make up his mind to go to Mars far away from the earth and end his life in the abyss of despair.

Thomas cannot forgive his father's infidelity all the time, but his mother has been puzzled by the estrangement between him and his father because she did not know the truth. In this family, the emotional estrangement between Thomas and his parents has caused emotional regret, that is, childhood trauma. This traumatic experience renders the characters have a sense of homelessness. The concept of home is ingrained in the consciousnesses of an individual, serving as the storage of memories. The image of home is usually soothing, and it suggests that Thomas is extremely eager for the community of blood.

In Chapter Ten through a dislocation of the blood community, the absence, on the contrary, shows Thomas' desire for a community of consanguinity. It can live on itself, thrive on memory alone, and overcome any distance by its feeling and its imagination of nearness and common activity. Nevertheless, it seeks all the more for physical proximity and is loath to give it up, because such nearness alone will fulfill the desire for love. "The ordinary human being, therefore - in the long run and for the average of cases - feels best and most cheerful if he is surrounded by his family and relatives. He is among his own" (Tönnies, 1980: 43) [14] .

Another family, whose mother died in a car accident, brought a fatal blow to the family. The father is encumbered with a large family and has to toil hard to support it. But the judge sentenced him to two years in custody. Ellie, the daughter in high school, took the strong responsibility of looking after the grandmother with Alzheimer disease and the younger brother in primary school. She tried to hold their ground during the time when her father left in prison. With their Grandma's mental condition getting worse and all the savings in the family were wiped out by phone fraud. Her small shoulder can no longer withstand the unexpected changes in life. The small family of them three is on the edge of separation. Thus, in this novel, Ellie's desire for the love of her parents is one embodiment of the community.

\subsection{Support from Siblings}

Emotional support from brothers and sisters is also a form of community of blood. "Real helpfulness, mutual aid, and advancement exist in the purest form among brothers and sisters because they tend to toward the same common activities. Besides difference in sex, difference in mental capacity necessarily becomes apparent in the brother-sister relationship. Accordingly, one side will be more concerned with brainwork, thinking and planning, while to the other side is given the manual labor, the task of execution" (Tönnies, 1980: 40) [14]. The community of blood is mainly reflected in the mutual support and assistance between Ellie, the daughter, and her younger brother, James, including her revenge for her little brother when her younger brother was suffered a lot from bullying at school. She also takes every possible effort to complete James' dream when her younger brother wanted to take part in the scientific experiment competition. In order to guarantee her younger brother's chemical experiment goes smoothly, she gave up her sleeping time to work and earn family's living expenses. She was so tired that her high school teacher even thought that she was addicted to drugs. Barnett uses the contrast between the character's psychological activities and external behavior to describe the little heroine's difficulty and grievances "She's kept it bottled up for so long. Had no one to talk to. Imagine if she just let it all go now, let the dam break. The words tumble out of her in a rush" (Barnett, 2017: 97) [1]. After school, she had to do three jobs to earn their living expenses without beautiful clothes, intimate girl friends or any love for a young boy. She always felt the darkness surrounding her, and was constantly buried under a mountain of work. But she never stopped trying hard to maintain the family, and took care of her grandmother and her brother. She did this so that the Welfare Department wouldn't separate their family and they can stay at home waiting for her dad to be out of prison and get this family back together. Ellie and James' parent cannot take care of them at that time, they must learn to paddle their own canoe. The siblings must have been tired and scared themselves but they did not quarrel, and they treated each other as precious.

\subsection{Intergeneration Communication}

The demographic changes in Britain from World War II to the present are similar to those in China, and there has been a progressive decrease in 
population. All kinds of development impact the family field, narrow its scope of activities and functions, cause intergenerational tension and estrangement, and its impact may be unprecedented. However, through the communication between James and his grandmother, we can see that the relationship between grandparents and grandchildren is both distant and intimate.

James slams the door behind him and heads straight for the stairs, ignoring Nan's calls from the kitchen enquiring who it is. He is halfway up the staircase when the tears come again, and he stops to force his fists into his eyes. Nan appears at the bottom of the stairs and looks up. Oh. It's you. James ignores her, sucking back his sobs, kneading his eyes until he sees stars and blobs of color. She tuts. 'Look at your blazer. Ellie won't be happy.' 'Stuff Ellie.' James carries on up the stairs. He hears Nan creaking up behind him. For God's sake, can't she just leave him alone? James heads straight into his bedroom and throws the door closed, leaning on it (Barnett, 2017: 59) [1]

Although James often gets angry and ignores his grandma words when he comes home because of the bullying at school, he still protects his grandma without hesitation when his model of competition is broken and the hope of protecting his family is about to be destroyed. And he never let Ellie put her anger on their grandma.

\section{COMMUNITY OF PLACE}

Community of place is a kind of common association or a specific communication mode. It is not only constructed by people's geographical connection but also supported by well-defined habits or other spiritual connections. This kind of community is depicted as a refuge - one where everybody could feel safe. They understand and respect the goal that anything worth having is worth pursuing.

\subsection{Families in Crises}

As Jubas (2006: 56) [7] explains, "The reinterpretation of community is another of globalization's outcomes. Globalization is challenging the structures, boundaries, values and practices of traditional communities as it brings individuals into new contact with one another". The first family: Thomas, the novel's protagonist, is a 47 years old man with great disillusionment. He let pain and disappointment engulf his soul and erode any desire to connect with human beings in any form. He seized the opportunity to become the first man on Mars with shameful agility.

And the other: Ellie, James and Gladys are not living what you call a happy life. Elle and James's father, Darin, was a good man who was still grieving the loss of his wife, Julie, who died at a drunk driver's hands four years earlier. Darin ended up in prison because he agreed to drive for a group of people he barely knew, and the job, as they often do, went wrong. His absence has left 15-year-old Ellie as the primary breadwinner for the family, juggling three part-time jobs, school and the care of James and her grandmother who, at 71 , is finding herself ever more lost to the initial ravages of dementia. "Gemeinschaft of locality may be conceived as a community of physical life, which is based on a common habitat" (Tönnies, 1980: 42) [14]. When people live under the same roof, the family constitutes a form of community community of place. Because the family deals with the same crisis together, it produces a common psychology to fight against the crisis, which also presents one aspect of community of place.

\subsection{The Earth and Outer Space}

In the chapter of outer space and earth, it mainly involves the dialogue between the astronaut Thomas and the little boy James in the novel. Here, it involves two different geographical spaces - the earth and outer space. Although the two people are in different geographical positions, the dialogue between the characters produces the ideological and psychological intersection of the two people, which can be seen as a community of place. "Although essentially based upon proximity of habitation, this neighborhood type of Gemeinschaft can nevertheless persist during separation from the locality, but it then needs to be supported still more than ever by well-defined habits of reunion and sacred customs" (Tönnies, 1980: 43) [14]. From the details of the article, it is analyzed that the astronaut Thomas guide the little boy to conduct a scientific experiment in the form of telephone calls in space. This call linking the earth and outer space is a form of spiritual communication and dialogue between them.

Was it? Thomas rubs his hand over his mouth. A shot at redemption? At this late stage? Is that all this is Just something to...what? To make himself feel better, as James so succinctly puts it? He looks out at the dwindling Earth again, and feels a sudden jolt. James is down there, somewhere, in the dark. 
James and Ellie and Gladys and Laura and Janet and all those people whose lives his intersected with. All those people. Claudia. And up here...nothing but Thomas. Not a single human being beyond him. Six billion of them on Earth, and he couldn't find it in him to be friends with a single one? The void is empty and weightless but abruptly he feels it pressing down on him from all sides(Barnett, 2017: 300) [1].

Through this phone call, we can see that the astronaut Thomas cares for the little boy and the little boy also feels that there is a kind and warm heart under the cold appearance of Thomas. They talked about scientific experiments and dreams, and at the end of the story, Thomas helped James realize his wish to win a prize in the competition in outer space. Although the little boy didn't know Thomas's childhood trauma, he deeply felt that Thomas could become a good father from his efforts for his dream. The trauma of the original family still left scars, the tribulations everyone received in growing up, the experience and precipitation during the time would open a new chapter in his life. The conversation between the two people here is one aspect of community of blood. This kind of community in the novel introduces the unusual interconnection between the characters, and their mutual support explains the positive impact of the community on people.

\subsection{Longing for Home}

The characters in the novel have one thing in common, and that is their longing for home. This can be said as a sense of belonging in modern society. The family of the little girl Ellie, in order to keep their house from being taken away by the government, did everything they could to protect it. Ellie was addicted in her part-time jobs. James took part in the science competition for the bonus, and grandma secretly hid the letter, which inform them to move. Even the dad in prison worked hard to maintain the family's expenses before he went to jail, and even took the risk of earning "part-time wages". These efforts all reflect their longing for a complete home. Lefebvre Henri (1991: 154) [8] points out in The Production of Space that "a residence contains certain social relations. It lives in a family - a special family represents a special country, group or land; it is a special place component." The term, house, is also well illustrated by others with following statement.

The house is the material foundation of a complete home, and the emotion is the spiritual bond that maintains the family (Quantrill, 1986: 90) [13].The house has a corresponding term in philosophy called the existence space. This space of existence is a deep-seated illustration that is deposited in human perception. This diagram carries a very stable perception diagram — the childhood memory of a person. On the symbolic level, our house is a symbol of our place in the world.

Houses are often given emotional attributes. Many people in real life have a strong emotional support for the houses they have lived in (Long, 2016: 43). So, the existence space is in the same way that longing for home. "The house constitutes the realm and, as it were, the body of kinship. Here people live together under one protecting roof. Here they share their possessions and their pleasures; they feed from the same supply, they sit at the same table" (Tönnies, 1980: 42-43) [14]. The house is the material basis of a complete home, and the emotion is the spiritual bond that sustains one family. Thus, longing for home constitutes a manifestation of the community of place.

\section{COMMUNITY OF MIND}

This chapter introduces the community of mind and a community of shared future. To show that there are still many people who choose to abandon self-interest and are willing to embrace any sacrifice to lay the foundation for the collective future. Explaining how community can cure innermost sadness on interpersonal connection.

\subsection{Resignation and Aspiration}

The community of mind is that people are not in the same place but have a lot in common in their spiritual world. The resignation here represents a kind of helplessness. In this article, Ellie is only a child, but she has to give up her studies and sleep to support her family. She is smarter than James, but because no one finds her talent. "Was it chance that James's potential was spotted and he was pushed to go to a better school, where it was just assumed Ellie - twice as bright as him, she scoffed to herself, ten times as bright - would go to the same old primary and same old comprehensive as everybody else from her street? Whether all that was chance or not, it was very rarely a fine thing" (40) [1]. She could only attend the little school and most of her classmates come from what they call "disadvantaged backgrounds." Ellie likes to read and immerse herself in the world of books. "Ellie 
wanders the aisles, running her fingers along the spines of the books. She loves book, loves the way they quiver softly with the weight of the words inside them. She just wishes she had time to read them" (40) [1]. But she has to give up this hobby and paralyze herself. When she saw the words "let the guardian attend" on the notice of her brother's, she tore the paper into pieces without a second thought. She did want her brother to enter for this scientific competition, but if she allowed her younger brother James to take part in that game, it may expose that there is no real guardian in the family, which may bring risks to the family. Grandma also made the corresponding compromise. A few years ago, she knew her illness and was not afraid of death or even yearning for the world after death. But she still chose to stay. She knew that it is not the right time to leave. Her son was still in prison. If she left the two kids, they would become homeless orphans.

Although her spirit was deteriorating, without the support of Ellie she would have probably cracked up completely, she eventually managed to hang on. In fact, the resignation here can also be understood as compromise under the community of mind. Because it is a spiritual community, we should support and contribute to each other. Work hard for each other's ideals and aspirations. Aspiration is about the characters' pursuit of their own ideals. In this paper, the ideal content of the characters in the novel takes little boy James as the main line to narrate that although the family was not well off and without adequate materials for scientific experiments, he still has a passion for Science. And the realization of his aspiration should be attributed to the collective efforts, through his cooperation with Thomas, Ellie and others. James is not the only one to achieve his dream. Many people reached out to him on the way to success. From the perspective of children's growth, James has become more and more confident and independent in the process of participating in the competition. He won the award, and regained his self-esteem and self-confidence. From the perspective of community, bullying in school and the lack of experimental materials provide James with the necessary conditions for growth. In the process of his growth, the active interaction and exchange among the characters make the community of mind more solid and full of vitality while accepting the test of reality. As Tönnies (1980: 43) said in the Community and Society friendship is independent of kinship and neighborhood, being conditioned by and resulting from similarity of work and intellectual attitude. It comes most easily into existence when crafts or callings are the same or of similar nature.

\subsection{Misery and Happiness}

Storms and rainbows, winters and springs, pain and happiness, these are the simplest antonym fillin-the-blank questions. One side of things is often exposed to the contrast of the other side. But it is precisely this kind of unconscious comparison that allows us to live a dark and painful life with a mentality of chasing future happiness. In order not to increase her father's anxiety, she worked hard to maintain the family. She had younger brother and grandma to support, money to be earned, and a home to be maintained. Ellie actually did not willing to bear such a heavy burden, but she had to carry it for her grandmother's mental condition was getting worse and her brother was being bullied by his classmates. Although her father made a mistake and was put in prison, Ellie learned dedication and determination from him. This is also the motivation to support her to voluntarily achieve a selfless state to protect her family. During her father's imprisonment, she gave up her friendship and material needs, and was ready to sacrifice everything for the family. "Ellie eats while Delil talks, and she envies him the easy, almost off-hand manner in which he speaks on anything and everything, bobbing from topic to topic like a bee in search of pollen. She wonders what it must be like to be so carefree, not to have to worry about grown-up things like Ellie does" (273) [1]. As Tagore said that Night's darkness is a bag that bursts with the gold of the dawn. The book concluded happily. Several emergency calls after James run away from home were the turning point in the story. These phone calls heated up the relationship among the characters. The atmosphere of the article also changed from negative to positive. After the last call, Thomas found his cure for his childhood trauma, and overcame the fear to go to space to fix the signal malfunction of the spacecraft. James strengthened his faith in completing the race. Ellie regained her hope of having a complete home. Grandma also realized her value on her way to London. Although her driver's license has expired for many years, she still safely drove them to the spot. Egoism is the better choice in most people's eyes. Many of them placed self-interest before the common good. But there are still some people who choose to abandon self-interest and are willing to embrace any 
sacrifice to lay the foundation for the collective future.

\subsection{Frustration and Consolation}

The character astronaut Thomas in the text has been in a low pressure in the first half of the novel. He always feels that he is a loser: whether his career, marriage, or even native family, he keeps reminding him that his life has fallen to the bottom. The characters under author's depicting cannot avoid frustration or making extreme choices. The little boy ran away from home after the experimental model was destroyed, his grandma hid the notice to quit, the little girl broke down and wept, Thomas wore the spacesuit. This frustration and consolation are actually experienced by many people in the modern life. This kind of community of mind is very mundane. As Tönnies said that not only does constant proximity and frequency of contacts mean mutual furtherance and affirmation, but inhibition and negation also become real possibilities or probabilities of a certain degree (1980: 44) [14].

We express unease with anger, and show dissatisfaction with silence; we love each other but we never express our gratitude or love just like a hedgehog with open spines. In the middle of the novel, beginning with the encounter between Thomas and the little boy James, Thomas got a feeling of being really needed from the little boy. In his decades of meaningless life, the little boy appeared like a light to break in his closed heart. He gained psychological comfort in his conversation with the little boy. Native family is a topic that we cannot avoid in society. But the native family is only your starting point. We cannot choose our own starting point, and we must never forget that our life contains infinite opportunities and dreams, overflows with inexhaustible vigor and charms, and bears limitless hope and success.

\subsection{A Community of Shared Future}

Community of shared future has revolutionary innovation significance in various aspects such as ideological implication, system conception, and etc. (Che, 2018: 175) [3]. The earliest concept of the community of human destiny was used to describe the special relationship between China and Taiwanthe political systems of the two sides are vastly different, but their destinies are closely related (Hughes, 2014) [6]. A community of shared future is like the characters in the text although they are faced with all kinds of difficulties, setbacks and dilemmas. Through the mutual connection between characters - the common psychological characteristics: "A community woven with mutual concern (Bauman, 2003: 186) [2]. Promoted by the community of minds, they gradually regained hope in the hard life, and the word that Thomas had racked his brains for was hope. Li Juhua (2018: 52) [9] holds that this kind of thought is the symbiotic consciousness in the community of shared future. So, this common connection actually points to the author's writing intention. It seems that Thomas helped the James family win the scientific experiment and save their family. To treat someone else as an end is to offer them what I take to be good reasons for acting in one way rather than another, but to leave it to them to evaluate those reasons. It is to be unwilling to influence another except by reasons which that other he or she judges to be good. It is to appeal to impersonal criteria of his or her own judge (Macintyre, 2007: 24) [11]. But in fact, in this process, the allies also helped Thomas to complete his own life salvation. Colonel Tom helped James win the game and finally redeemed himself. This event let him know that he is not far away from the earth, but he is still needed. So do not lose hope, empathy is hardwired into our species. When we take care of each other, the pleasure centers of our brains light up. Just knowing about that a bit of kindness feels like a balm for our collective souls in this era of bitter fights and bloated egos.

\section{CONCLUSION}

Calling Major Tom takes place at the beginning of the 21st century. Economic globalization has gradually developed. Commercial, cultural, travel and other contacts have proliferated among countries all over the world. Mankind has established universal exchanges and interconnections among countries in the world, breaking through a community that used blood or region as a common attribute or bond (Wang and Miao, 2019: 33) [15]. There has been a sharp slowdown in economic growth, and the population continues to grow. There is too much emphasis on individualism and insufficient attention to the collective responsibility of society (Young, 1989: 417) [16]. On the case of rising prices, people at the bottom of the society are going through a very difficult time. The lack of material resources also affected people's spiritual world, which makes the individual in the society increasingly lack of security. 
Such fictional communities help the reader understand real communities, including those in which the reader lives (Miller, 2014) [12]. The optimistic ending of the novel also reveals the author's writing attitude: affirmation of infinite possibilities in the future. Thus, we must regard all humankind as a community of shared future, the international community as a family of the world, and jointly build a community with shared future for humanity to meet the challenges.

In the post-9/11 era, human beings are exposed to uncertainties, and individuals savor clearly the flavor of the splitting state between a specific person and the world. The motifs of modernistic novels, such as alienation, loneliness and frustration, find their way to contemporary literary works, in an intensified way. Nevertheless, human beings do have sense and sensibility, and tend to show empathy and sympathy when disasters and agony make circumstances lamentable. A community of shared future lends hope to the very family in the novel. It alleviates the fragility and fickleness of an individual's life, and shared responsibility comes into being. One person's welfare is much related to that of another, and a community is supposed to be formed for people to share weal and woe. Love, faith and hope are secured in Calling Major Tom.

\section{AUTHORS' CONTRIBUTIONS}

Yuan Shen is responsible for writing the paper, and Quan Yuan is responsible for data collection.

\section{REFERENCES}

[1] Barnett, David. Calling Major Tom[M]. London: Trapeze, 2017.

[2] Bauman, Zygmunt. Community[M]. Trans. Ouyang Jinggen. Jiangsu: Jiangsu People's Publishing House, 2003.

[3] Che, Zhou. Community of Human Destiny: Literature Review of Researches at Home and Abroad and Further Discussion[J].Theory and Reform, 2018, (5): 175-187.

[4] Fei, Xiaotong. From the Soil — The Foundations of Chinese Society[M]. Beijing: Peking University Press, 2012.

[5] Huang, Ziyi. Community and the Symbolic Matrilineal Consanguinity: Knowledge, Order and Morality in From the Soil — The
Foundations of Chinese Society[J]. Journal of Ethnology, 2016, (4): 47-55.

[6] Hughes, C. When Big Powers Pivot, the Little States Roll: Southeast Asia between China and Japan[J]. The Asian Forum, 2014, (6): 12-14.

[7] Jubas, Kaela. A Fine Balance in Truth and Fiction[J]. International Journal of Lifelong Education, 2014, (24): 54-69.

[8] Lefebvre, Henri. The Production of Space[M]. Oxford: Blackwell, 1991.

[9] Li, Juhua. Community with a Shared Future in Human Voices[J]. Journal of Hunan University of Science and Technology (Social Science Edition), 2018, (6): 52-56.

[10] Long, Juan. "Houses" in Housekeeping in the Light of the Theory of Place[M]. Foreign Literature, 2016, (2): 41-50.

[11] Macintyre, Alasdair. After Virtue[M]. North Bend: University of Notre Dame Press, 2007.

[12] Miller, Hillis. Communities in Fiction[M]. New York: Fordham University Press, 2014

[13] Quantrill, Malcoln. Environmental Memory: Man and Architecture in the Landscape of Ideas[M]. New York: Schocken, 1986.

[14] Tönnies, Ferdinand. Community and Society[M]. New York: Routledge, 2017.

[15] Wang, Qingfeng \& Miao, Cuicui. The Philosophy Idea of Comunity of Shared Future for Mankind[J]. The Northern Forum, 2019, (6): 27-36.

[16] Yuong, Hugo. The Iron Lady: A Biography of Margaret Thatcher[M]. New York: Farrar Strauss Giroux, 1989. 